\title{
PERAN LITERASI BAHASA DALAM MENINGKATKAN MINAT BACA DAN MENULIS PADA SISWA SMP KOTA BEKASI
}

\author{
Aster Pujaning Ati*1, Sigit Widiyarto ${ }^{* 2}$ \\ ${ }^{1,2}$ Universitas Indraprasta PGRI Jakarta \\ e-mail: *11asterpujaningati@ymail.com, ${ }^{2}$ sigit.widiyanto372@gmail.com
}

\begin{abstract}
ABSTRAK
Budaya membaca dan menulis dikalangan siswa masih rendah, perlu adanya upaya sungguh - sungguh dari berbagai kalangan. Tujuan penelitian ini untuk mendeskripsikan peran literasi bahasa dalam meningkatkan minat baca pada siswa SMP Attaqwa Bekasi. Metode yang digunakan adalah metode kualitatif deskriptif. Sumber data penelitian ini adalah kepala sekolah, guru dan siswa dengan menggunakan teknik pengumpulan data melalui wawancara, observasi dan dokumentasi. Keabsahan data penelitian ini menggunakan trianggulasi sumber dan trianggulasi teknik. Data dianalisis secara interaktif yang terdiri dari pengumpulan data, reduksi data, penyajiandata, penarikan kesimpulan dan verifikasi.Responden sebanyak 25 siswa SMP kelas VII. Penelitian ini dilaksanakan pada bulan Desember 2019 sampai dengan Februari 2020. Berdasarkan data yang terkumpul, kemudian didiskripsikan dan dianalisis. Penulis dapat menarik kesimpulan bahwa 1) kegiatan literasi di SMP Attaqwa berperan dalam memotivasi siswa untuk menyukai kegiatan membaca dan menulis, 2) hambatan pihak sekolah dalam meningkatkan minat membaca dan menulis siswa kelas atas melalui kegiatan literasi yakni kedisiplinan, pembiasaan siswa, minat, dan metode yang diterapkan guru, dan 3) upaya pihak sekolah untuk meningkatkan minat membaca dan menulis siswa kelas atas melalui kegiatan literasi adalah pihak sekolah selalu memberikan sosialisasi mengenai kegiatan literasi, mengenalkan pentingnya menumbuhkan minat dan mengadakan lomba-lomba sebagai wadah siswa untuk berpartisipasi aktif.
\end{abstract}

Kata Kunci : peran, literasi bahasa, minat baca, menulis

\section{A.PENDAHULUAN}

Upaya pemerintah dalam meningkatkan pendidikan khususnya pada bidang minat baca, terus . Gerakan literasi sekolah (GLS) yang sudah dilaksanakan masih perlu diperbaiki, baik teknis maupun dari segi regulasi GLS merupakan kemampuan mengakses, memahami, dan menggunakan sesuatu secara cerdas melalui berbagai aktivitas, antara lain membaca, melihat, menyimak, menulis dan atau berbicara (Faizah, 2016:2). Kemampuan pada literasi bahasa sangat strategis dalam mengembangkan kompetensi siswa nanti. Di era 4.0 siswa harus mengkolaborasi kemampuan literasi dengan kemampuan literasi digital. Bahkan kompetensi literasi pada kelas tinggi mengharuskan siswa untuk dapat melakukan analisa secara kritis, seperti melakukan interviu, pengamatan lingkungan, menulis laporan, dan melakukan observasi ( Widodo dkk 2015). Pada era 4.0 kemampuan guru juga dituntut dapat mengimbangi luaran yang ada pada siswa. Alwasilah (2012:177) mengemukakan bahwa mengajarkan literasi pada intinya menjadikan manusia yang secara fungsional mampu berbaca-tulis, terdidik, cerdas, dan menunjukkan apresiasi terhadap sastra. Dikarenakan selama ini pendidikan 
di Indonesia mampu mencetak lulusan yang terdidik namun kurang memiliki apresiasi terhadap sastra.

Secara umum kemampuan literasi ialah bagaimana mengajarkan siswa agar giat membaca dan menulis. Dalam hal ini maka diperlukan kreativitas guru dalam menentukan cara yang efektif dan efisien (Widodo dkk, 2015:61). Kegiatan membaca dan menulis yang dikerjakan siswa ,masihlah kurang. Hal ini menjadi perhatian para pendidik dan pemerintah. Budaya bercerita sebelum tidur, turut menyumbang ,kebiasaan ank yang ebih baik mendengar ketimbang membaca dan menulis.

Rendahnya literasi di Indonesia disebabkan oleh masyarakat yang kurang sadar akan manfaatnya. Lebih dari itu, beberapa orang bahkan masih belum mengerti makna literasi. Literasi adalah kemampuan membaca dan menulis. Keduanya belum menjadi budaya di negara kita. Padahal, perkembangan ilmu dan budaya harus dimulai dari keduanya. Beberapa lembaga survei menyatakan fakta tentang rendahnya budaya literasi di Indonesia. Programme for International Student Assessment (PISA) menyebutkan, pada tahun 2012 budaya literasi di Indonesia menempati urutan ke-64 dari 65 negera yang disurvei. Pada penelitian yang sama ditunjukkan, Indonesia menempati urutan ke57 dari 65 negara dalam kategori minat baca. Data Unesco menyebutkan posisi membaca Indonesia $0.001 \%$ - artinya dari 1.000 orang, hanya ada 1 orang yang memiliki minat baca. Hasil survei tersebut cukup memprihatinkan.

Untuk itu semua pemegang kepentingan dalam pendidikan harus dapat membantu, agar siswa mempunyai minat baca dan menulis dengan baik. Berangkat dari uraian diatas penulis ingin mendeskripsikan peran literasi untuk meningkatkan minat baca dan menulis pada siswa SMP Attaqwa Kabupaten Bekasi. Pemilihan lokasi didasarkan atas saran dinas penddikan setempat, dan merupakan sekolah yang sudah cukup lama berdiri. Sekolah berdiari sejak tahun 2001.

\section{B.KAJIAN TEORI}

\section{Literasi}

Literasi adalah perilaku sosial seseorang dalam mengakses, memahami, dan menggunakan informasi yang terkait dengan pengetahuan, bahasa dan budaya melalui berbagai aktivitas, antara lain membaca, melihat, menyimak, menulis dan berbicara untuk melahirkan kesejahteraan hidup . Pada kehidupan sehari - hari para siswa dihadapkan dengan tugas dan ketrampilan yang menggunakan literasi . Sedangkan literasi bahasa mengharuskan siswa dapat melek huruf, termasuk kemampuan membaca dan menulis.Berikut skema pelaksanaan strategi literasi di sekolah (Kemdikbud 2017). 


\section{Tiga Tahapan Pelaksanaan Literasi Sekolah}

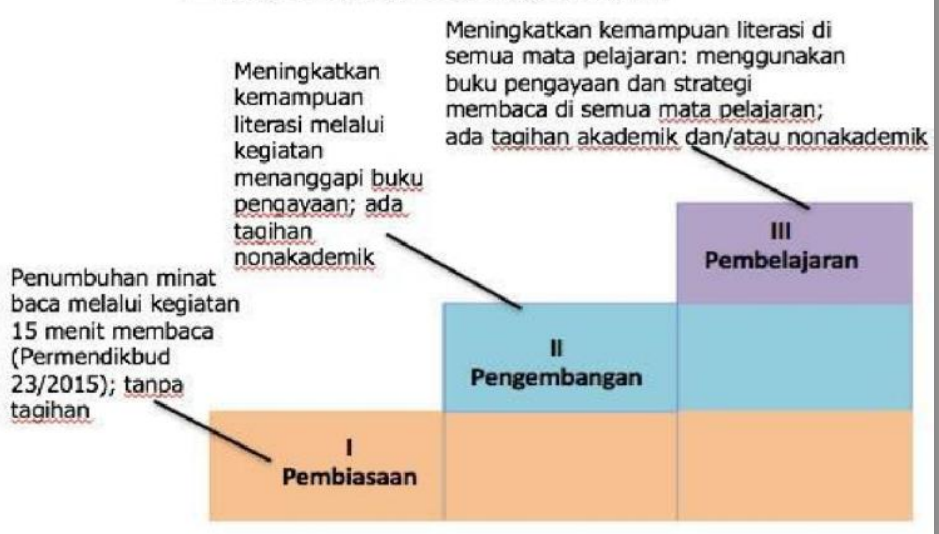

\section{Gambar 1.Skema Tahap Pelaksanaan Literasi Sekolah}

Tahapan pelaksanaan literasi di sekolah merupakan upaya pemerintah untuk dapat meningkatkan kemampuan literasi siswa. Pada tahapan awal, siswa diharapakan dapat membaca selama 15 menit . Kegiatan ini dapat dilakukan diawal pelajaran, dan merupakan rangkaian kegiatan pembelajaran sekolah.

Pada tahapan kedua, siswa dapat memberikan pendapat, memberikan penilaian, bercerita atau menganggapi isi materi yang sudah dibaca oleh siswa. Siswa dapat membawa tugas tersebut kerumah, untuk menjadi pekerjaan rumah ( PR). Pada tahapan ini, peran orang sangat diperlukan. Dengan bantuan dan motivasi orang tua, siswa akan termotivasi untuk melaksanakan kegiatan literasi di rumah.

Pada tahapan akhir literasi, siswa diharapkan mendapat pemahaman yang baik, tenang literasi. Semua mata pelajaran sudah menjadi bagian integral dari literasi. Semua pelajaran dan guru sudah melaksanakan pembelajaran literasi.

\section{Minat Baca}

Minat adalah kecenderungan afektif (perasaan, emosi) seseorang untuk membentuk aktifitas. Dari sini dapat dilihat bahwa minat itu melibatkan kondisi psikis(kejiwaan) seseorang. Senada dengan hal ini, Crow dan Crow (Dwi Sunar Prasetyono, 2008: 54),menjelaskan bahwa minat merupakan kekuatan pendorong yang menyebabkan seseorang menaruh perhatian pada orang lain atau objek lain. Sementara itu Hurlock (Dwi Sunar Prasetyono, 2008: 54),mengutarakan pendapat yang sama yaitu bahwa minat merupakan sumber motivasi sama, yaitu bahwa minat merupakan sumber 
motivasi untuk melakukan apa yang mereka inginkan bila mereka bebas memilih. Minat merupakan rasa lebih suka dan rasaketertarikan pada suatu hal atau aktifitas, tanpa ada yang menyuruh (Slameto, 2010: 180). Menurut Hurlock (Hermanto Blogs, 2011), mengartikan minat sebagai sumber motivasi yang akan mengarahkan seseorang pada apa yang akan mereka lakukan bila diberi kebebasan untuk memilihnya. Bila mereka melihat sesuatu itu mempunyai arti bagi dirinya, maka mereka akan tertarik terhadap sesuatu itu yang pada akhirnya nanti akan menimbulkan kepuasan bagi dirinya.

\section{Menulis}

Menulis berarti mengekspresikan secara tertulis gagasan, ide, pendapat, atau pikiran dan perasaan yang diwujudkan dalam bahasa. Isi ekspresi melalui bahasa itu akan dimengerti orang lain atau pembaca bila dituangkan dalam bahasa yang teratur, sistematis, sederhana dan mudah dimengerti. Disamping itu sebuah tulisan dikatakan baik apabila bermakna, jelas, bulat, utuh, ekonomis, dan memenuhi kaidah gramatika.Menurut pendapat Burhan Nurgiyantoro (2001: 273),menulis adalah aktivitas mengungkapkan gagasan melalui media bahasa. Menulis merupakan kegiatanproduktif dan ekspresif sehingga penulis harus memiliki kemampuan dalam menggunakan kosakata, tata tulis,dan struktur bahasa

Selain itu, menulis juga merupakan suatu aktivitas komunikasi yang menggunakan bahasa sebagai medianya.Dengan menulis dapat melatih kita untuk berpikir kritis dan logis (Ati, A. P., dkk .2018). Wujudnya berupa tulisan yang terdiri atas rangkaian huruf yang bermakna dengan semua kelengkapannya, seperti ejaan dan tanda baca. Menulis juga suatu proses penyampaian gagasan, pesan, sikap, dan pen-dapat kepada pembaca dengan simbol-simbol atau lambang bahasa yang dapat dilihat dan disepakati bersama oleh penulis dan pembaca.

Menulis merupakan suatu keterampilan berbahasa yang dipergunakan untuk berkomunikasi secara tidak langsung, tidak secara tatap muka dengan orang lain. Menulis merupakan kegiatan produktif dan ekspresif.Sebagai bagian kegiatan berbahasa, menulis berkaitan erat dengan aktifitas berpikir. Keduanya saling melengkapi, sehubungan dengan itu, menulis dan berpikir merupakan dua kegiatan yang dilakukan secara bersama dan berulang-ulang. Tulisan adalah wadah yang sekaligus merupakan hasil pemikiran.

Selanjutnya menulis bertujuan untuk menyenangkan para pembaca, menghindarkan kedudukan para pembaca, ingin menolong para pembaca memahami, menghargai perasaan, dan penalarannya, ingin membuat hidup para pembaca lebih mudah dan lebih menyenangkan dengan karyanya itu. Selain menyenangkan pembaca ,menulis juga dapat 
sebagai persuasif Purpose. Menulis merupakan kemampuan yang berhubungan dengan kemampuan lain seperti kemampuan membca dan berbicara.

\section{METODE PENELITIAN}

Peneliti mengunakan metode penelitian kualitatif deskriptif. Penelitian deskriptif dilaksanakan agar dapat mendeskripsikan hal yang sesuai tentang sebuah variabel yang belum dapat dikatakan "real", dengan pengambilan data yang sudah dikumpulkan dan dianalisis lalu disimpulkan secara sistematis dan akurat. Desain penelitian digunakan untuk memaparkan proses penelitian yang akan dilakukan. Penelitian dilakukan di SMP Attaqwa kabupaten Bekasi selama 3 bulan.

Data primer didapat dari teknik observasi, dokumentasi dan wawancara yang disampaikan oleh responden yakni kepsek, guru dan siswa kelas atas SMP Attaqwa. Peneliti melakukan kegiatan secara langsung . peneliti dilapangan dibantu satu orang observer agar dapat mengambil dokumen serta bukti-bukti yang urgent. Data lalu dianalisis data sebagai salah satu langkah penting untuk menganalisis temuan-temuan penelitian dengan mereduksi data, menyajikan data dan memverifikasi data. Penelitian ini menggunakan jenis triangulasi teknik dan triangulasi sumber guna memperoleh data yang diperlukan. Data diperoleh dari narasumber yang berperan serta dalam penelitian. Untuk menggambarkan kendala dan hambatan kegiatan literasi disekolah dan dirumah peneliti memberikan angket daring kepada siswa. Angket diberikan kepada 45 siswa kelas VII dan VIII.

\section{HASIL DAN PEMBAHASAN}

\section{Peran Literasi Bahasa di SMP Attaqwa.}

Peran literasi bahasa pada saat siswa di sekolah dan dirumah perlu ditinjau. Hal ini dapat dilihat kebiasaan siswa di rumah dan di sekolah . Para guru di disekolah memberikan pemahaman ,akan pentingnya literasi bahasa kepada para siswa. Hal ini diteruskan kepada para orang tua wali, pada pertemuan sosialisasi literasi di sekolah Kepala sekolah mendukung program ini, dengan mencatat dan mendata jumlah buku yang disiapkan di sekolah. Para guru memerikan motivasi dan reward bagi siswa yang dapat menyelesaikan tugas - tugas yang berkaitan dengan literasi bahasa, sebagai contoh tugas membaca, dan menceritakan ulang, serta menyadur sebuah cerita rakyat. Kegiatan ini sebaiknya di bantu dan dikomunikasikan dengan para orang tua di rumah sebab siswa akan lebih leluasa untuk mengembangkan kemampuannya .Hal ini sesuai dengan pendapat, LeFervedan Senechal (1999: 3) menyatakan bahwa lingkungan rumah adalah sumber kemungkinan pengalaman yang dapat meningkatkanperkembangan bahasa lisan dan keterampilan keaksaraan awal. 
Hal ini dapat diartikan bahwa di rumah merupakan awal siswa belajar dan mengembangkan segala kemampuannya termasuk literasi bahasa.

\section{Upaya Sekolah Untuk Meningkatkan Minat Baca Dan Menulis}

Para siswa sebelum memasuki kelas pada hari jumat, diwajibkan membaca Alquran sebanyak 1 lembar. Hal ini merupakan suatu upaya agar siswa dapat meningkatkan minat baca. Upaya lain yang dilakukan sekolah yaitu membuat jadwal kunjungan ke perpustakaan, seminggu 2 kali. Siswa bergilir memasuki perpustakaan, guru membimbing , agar siswa membaca buku dengan baik dan tertib. Berselang 1 minggu, siswa diharuskan melaporkan apa yang sudah dibaca selama 1 minggu. Laporan tersebut berupa laporan tertulis. Upaya lain yang dilakukan pihak sekolah untuk meningkatkan minat baca dan menulis, sekolah mengadakan lomba menulis cerpen dan baca puisi. Hal ini dilakukan pada saat bulan bahasa Oktober. Hal ini patut diapresiasi, sebab siswa lebih bersemangat membaca dan menulis melalui pembiasaan selama pihak sekolah mendukung dan memfasilitasi kegiatan literasi bahasa. Upaya pembiasaan ini dapat dikategorikan menjadi dua bentuk, yakni 1) pembiasaan melalui pengembangan atau penciptaan budaya literasi, dan 2) pembiasaan melalui pembelajaran di kelas melalui berbagai mata pelajaran. Kedua jenis/bentuk kegiatan ini memiliki tujuan yang sama yaitu menanamkan kebiasaan membaca dan menulis pada diri siswa ( Subandiyah. 113 : 2017)

\section{Faktor - Faktor Penghambat Sekolah Dalam Meningkatkan Minat Baca Dan Menulis Siswa}

Peneliti melihat masih ada hambatan yang dihadapai sekolah dalam meningkatkan minat baca dan menulis yaitu :

a. Siswa masih belum dapat membiasakan membaca di rumah, hal ini masih perlu dikomunikasikan kepada para orang tua murid.

Pada pembiasaan membaca dirumah, para orang tua perlu menyempatkan waktu ,untuk mengawasi dan memberika motivasi dengan memberikan punishment dan reward. Pendidikan dirumah merupakan pendidikan inti dalam keluarga. Pembiasaan yang dilakukan siswa dirumah ,akan tercermin disekolah.

b. Kesadaran siswa untuk berkunjung ke perpustakaan belum optimal.

Kesadaran merupakan upaya atau kegiatan yang dilakukan tanpa paksaan, dan tidak ada pengaruh luar . Literasi yang didasari oleh kesadaran, dan kerelaan akan melahirkan pembiasaan yang ajek dan konsisten. Siswa yang sudah mempunyai kesadaran tinggi untuk berkunjung ke perpustakaan, tentunya siswa yang sudah terbiasa membaca, 
c. Masih ada orang tua yang tidak mendukung program literasi bahasa.

Kebiasaan orang tua akan dituri oleh oleh anak. Tanpa sadar orang tua sudah memberikan kebiasaan yang kurang tepat pada anak. Untuk itu perlu pendidikan literasi kepada para orang tua, agar sekolah dapat bekerjasama dengan para orang tua untuk mengadakan parenting education

d. Jenis buku di perpustakaan sekolah masih perlu ditingkatkan, baik dari segi jumlah dan kualitas buku.

Sarana dan prasaran perpustakaan dan jumlah serta kualitas pelayaaan, ikut andil dalam pembelajaran literasi di sekolah. Perpustakaan merupakan jantung dari pembelajaran di sekolah, untuk itu perhatian khusus perlu dilakukan oleh pihak sekolah dan para orang tua .

Pada pelaksanaan membaca diharapkan pihak guru dan siswa mempunyai jadwal tetap membaca. Sesuai dengan angket yag diberikan kepada para siswa ,maka didapat grafik 1, sebagai berikut :

Grafik 1 Tabel Kendala Literasi

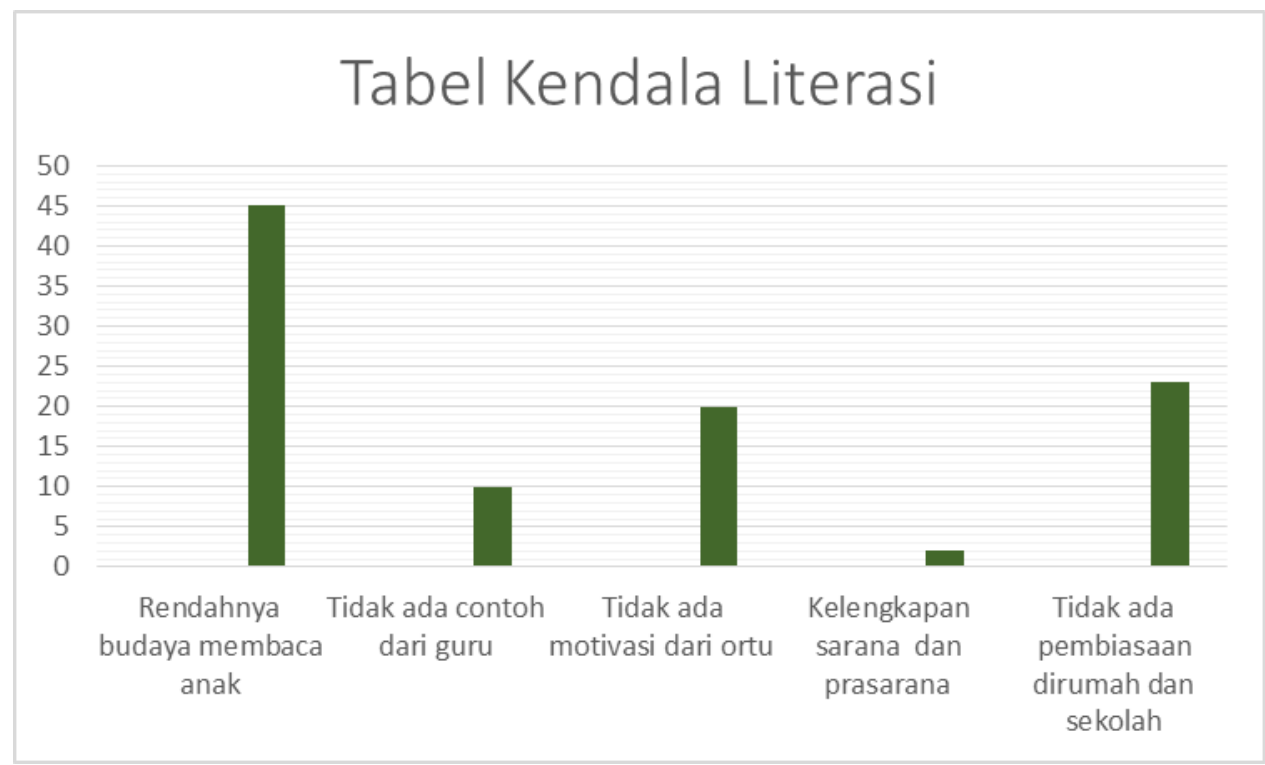

Pada grafik di atas nampak rendahnya budaya membaca pada anak mendominasi kendala dalam rangka peningkatan literasi, sebesae $45 \%$. Hal ini dapat dirubah bertahap, dengan pembimbingan dari rumah. Para orang tua wajib untuk memberikan contoh dan sekaligus mengerjakan, sehingga anak mempunyai role model belajar serta literasi bahasa yang baik dirumah . 
Pembiasaan dirumah, nampak pada data, sebanyak $20 \%$ siswa menyatakan tidak ada motivasi dar orang tua, serta $10 \%$ dari guru, sarana dan prasaran sebanyak $2 \%$,serta tidak ada pembiasaan membaca sebanyak $23 \%$.

\section{E.KESIMPULAN}

Simpulan yang dapat di paparkan adalah, 1) siswa sudah mulai tumbuh untuk menulis dan membaca, 2) para guru sudah maksimal dalam mengupayakan literasi bahasa disekolah. 3) peran para orang tua perlu ditingkatkan untuk dapat memperhatikan dan sekaligus memotivasi anaknya dirumah. Para guru dapat menggunakan metode yang bervariasi dalam menerapkan pembelajaran membaca dan menulis di kelas. Para orang tua wali murid terus memantau program literasi disekolah.Rendahnya budaya membaca anak $45 \%$, tidak ada contoh dari guru sebesar $10 \%$, tidak ada motivasi orang tua $20 \%$ kelengkapan sarana dan prasarana $2 \%$ dan tidak ada pembiasaan dirumah dan disekolah sebesar $23 \%$.

\section{F. SARAN}

Strategi peningkatan literasi bahasa perlu ditingkatkn dengan cara mengajak seluruh komponen yang ada disekolah.Guna memberikan motivasi kepada siswa, para orang tua dan guu sebaiknya dapat memberi contoh suri tauladan. Dirumah siswa dapat membaca bersama - sama dengan orang tua mereka, sedangkan di sekolah mereka dapat dibombing oleh guru. Petugas perpustakaan juga dapat membantu pembiasaan membaca disekolah, sehingga tingkat kehadiran perpustakaan dapat meningkat.

\section{DAFTAR PUSTAKA}

Alwasilah, A.Chaedar. 2012. Pokoknya Rekayasa Literasi. Bandung: PT Kiblat Buku Utama

Ati, A. P., Widiyarto, S., \& Suyana, N. (2018). Penerapan Metode Picture And Picture Untuk Peningkatan Keterampilan Menulis Narasi Pada Siswa Kelas VIII SMP Al Ihsan Dan SMP Tashfia Kota Bekasi. Adimas: Jurnal Pengabdian Kepada Masyarakat, 2(1), 30-36.

Faizah, Dewi Utama dkk. 2016. Panduan Gerakan Literasi Sekolah Di Sekolah Dasar. Jakarta: Direktorat Jendral Pendidikan Dasar Dan Menengah Kementrian Pendidikan Dan Kebudayaan

Kharizmi, M. (2019). Kesulitan siswa sekolah dasar dalam meningkatkan kemampuan literasi. Jurnal Pendidikan Almuslim, 7(2).

Kemdikbud. (2017). Strategi Literasi dalam Pembelajaran di sekolah Menengah Pertama: Materi Penyegaran Instruktur Kurikulum 2013.

LeFerve, Jo-Anne dan Senechal, Monique. (1999). The relations among home-literacy factors, language and early-literacy skills, and reading uisition.EducationalResources Information Center (Eric). April 1999 halaman 1-1

Prastyo DS,2008, Rahasi Mengajarkan anak gemar membaca,Jogyakarta : Think 
Subandiyah, H. (2017). Pembelajaran literasi dalam mata pelajaran bahasa Indonesia. Paramasastra, 2(1).

Suhaimi, I. (2017). Memberdayakan Kecerdasan Kinestetik Anak Untuk Budaya Literasi Bahasa. KREDO: Jurnal Ilmiah Bahasa dan Sastra, 1(1), 72-90.

Nurdiyanti, E., \& Suryanto, E. (2010). Pembelajaran Literasi Mata Pelajaran Bahasa Indonesia pada Siswa Kelas V Sekolah Dasar. Paedagogia, 13(2).

Nurgiyantoro, Burhan. 2001. Penilaian dalam Pengajaran Bahasa dan Sastra Indonesia.Yogjakarta: BPFE.

Rahayu, T. (2016). Penumbuhan Budi Pekerti Melalui Gerakan Literasi Sekolah

Taminufin. 2008. " Pembelajaran Menulis Karangan Deskripsi dengan Menggunakan Metode Gambar sebagai Upaya Meningkatkan Keterampilan Menulis (Penelitian Tindakan Kelas VII MTs PUI Kancana Kabupaten Majalengka Tahun Ajaran 2007/2008)". Skripsi. Surakarta: UN

Mubasyira, M. (2017). Analisis Tokoh dan Penokohan Dalam Film My Name is Khan Karya KaranJohar. Wacana Didaktika, 5(02), 133-142.

Suyana, N., Ati, A. P., \& Widiyarto, S. (2019). Metode Partisipatori untuk Meningkatkan Kemampuan Menulis Argumentasi Pada Siswa MTs Nurul Hikmah Kota Bekasi. Linguista: Jurnal Ilmiah Bahasa, Sastra, dan Pembelajarannya, 2(2), 80-86.

Resmini, N. (2013). Orasi dan Literasi dalam Pengajaran Bahasa. Tersedia [online] juga dalam http://file. upi. edu/Direktori/FPBS/JUR.__PEND. _BHS. _DAN_SASTRA_INDONESIA/196711031993032NOVI_RESMINI/ORASI_DAN_LI TERASI_DALAM_PENGAJARAN_BAHASA. pdf [diakses di Cianjur, Indonesia: 20 Agustus 2013].

Widodo, Slamet dkk. 2015. Membangun Kelas Literat Berbasis Pendidikan Lingkungan Hidup Untuk Melatihkan Kemampuan Literasi Siswa Di Sekolah Dasar. Prosding Seminar Nasional Pendidikan. Diakses pada 24 Januari 2020 